\title{
Lactation decreases pancreatic lipase mRNA level in the rat*
}

\author{
Ruth Z. Birk††, Karen S. Regan§ and Patsy M. Brannon\| \\ Department of Nutrition and Food Science, University of Maryland, College Park, MD 20742, USA \\ (Received 11 November 2004 - Revised 20 June 2005 - Accepted 23 June 2005)
}

\begin{abstract}
Lactation alters maternal metabolism and increases food intake in rats to support milk production. Pancreatic lipase (PL) is primarily responsible for fat digestion in adults and is regulated by dietary fat. The present research determined the regulation of PL by lactation and dietary fat. In Expt 1, eighteen Sprague-Dawley dams and twelve age-matched virgins (controls) were fed a low-fat diet (LF; $11 \%$ energy as safflower oil) for 7-63 d. At postpartum (day 0), peak lactation (day 15) and post-lactation (day 56) and after $7 \mathrm{~d}$ in virgins, the pancreas was removed for mRNA and enzyme analyses. In Expt 2, thirty-six Sprague-Dawley dams were fed LF until day 9 postpartum when dams were divided into three groups of twelve; one continued to be fed LF, one was fed a moderate-fat diet (MF; $40 \%$ energy as safflower oil); and one was fed a high-fat diet (HF; $67 \%$ energy as safflower oil) diet. At peak lactation (day 15) and post-lactation (day 56), the pancreas was removed for mRNA and enzyme analyses. Expt 1 revealed that lactation and post-lactation significantly $(P<0.001)$ decreased PL mRNA (67\% and 76\%, respectively), but only post-lactation decreased PL activity. Increased dietary fat in Expt 2 significantly increased PL mRNA (LF $<$ MF $<$ HF, $P<0.001$ ) and PL activity (LF $<$ MF $=\mathrm{HF}, P<0.02$ ) in both lactation and post-lactation. In summary, lactation and post-lactation decreased PL mRNA significantly even though dietary fat still regulated PL activity and mRNA in lactation and post-lactation.
\end{abstract}

Lactation: Pancreatic lipase: mRNA: Dietary fat

During lactation in the rat, there are multiple physiological and metabolic changes that support milk production in the mammary gland. Because rats store only a limited amount of fat during pregnancy, their food intake more than triples in order to meet the demands of milk production during lactation (Williamson, 1980; Shirley, 1984). When lactating rats are fed a standard low-fat (LF) diet, approximately $50 \%$ of milk lipids are synthesized by the mammary gland and $50 \%$ are supplied by the diet. Increased dietary fat decreases mammary-gland lipogenesis and results in the conservation of glucose for both maternal energy and milk production (Williamson, 1980). In addition, rats become energetically more efficient during lactation by expending significantly less energy on activity and maintenance (Roberts \& Coward, 1984). The intestine, liver and mammary gland increase in weight (Mainoya, 1978; Williamson, 1980; Garcia-Caballero et al. 1996), as do the pancreas and spleen (Barrowman \& Mayston, 1973; Matsuda et al. 1995). Cardiac output is also increased, as is blood flow to the digestive tract and the mammary gland (Williamson, 1980). Exocrine pancreatic secretion (Barrowman \& Mayston, 1973) and the absorptive capacity of the small intestine (Cripps \& Williams, 1975; Mainoya, 1975; Oller do Nascimento \& Williamson, 1986), including lipid absorption (Oller do Nascimento \& Williamson, 1986), are also increased during lactation.

Pancreatic lipase (E.C.3.1.1.3; PL) plays an important role in the absorption of dietary fat by hydrolysing triacylglycerols into diacylglycerols, monoacylglycerols and NEFA. In man, PL hydrolyses $56 \%$ of the triacylglycerols in a test meal with an additional $10 \%$ hydrolysed by gastric lipase (Carriere et al. 1993). PL is regulated by both the amount (Sabb et al. 1986; Wicker et al. 1988; Ricketts \& Brannon, 1994) and the type (Sabb et al. 1986, Ricketts \& Brannon, 1994) of dietary fat. Maximal activity is seen with high-fat (HF) diets irrespective of type of fat (Sabb et al. 1986). PL responds to the type of fat (saturated/unsaturated and chain length) as well, with unsaturated, long-chain fats eliciting the greatest response in moderatefat (MF) diets (Ricketts \& Brannon, 1994). The amount of dietary fat, independent of its type, regulates the transcription of PL (Wicker \& Puigserver, 1990), while the type of dietary fat regulates the translation or post-translation of PL (Ricketts \& Brannon, 1994).

PL mRNA and activity during lactation have not been studied. The purpose of the present study was to determine the effect of lactation and its interaction with dietary fat on PL in the rat.

\footnotetext{
Abbreviations: HF, high-fat; LF, low-fat; MF, moderate-fat; PL, pancreatic lipase.

* Presented in part at Experimental Biology Society Meeting, April 1999, Washington DC, USA (Regan et al. 1999).

$\dagger$ Corresponding author: Dr. Ruth Z. Birk, fax +972 8 6472983, email rbirk@bgu.ac.il

$\ddagger$ Present address: Department of Biotechnology Engineering, Ben Gurion University, Beer Sheva, Israel 84015.

$\S$ Present address: Division of Nutrition Research Coordination, National Institutes of Health, Bethesda, MD 20892-5461, USA.

|| Present address: Division of Nutritional Sciences, 225 Savage Hall, Cornell University, Ithaca, NY 14853, USA.
} 


\section{Materials and methods}

\section{Experimental design}

Sprague-Dawley virgin and pregnant rats were purchased from Charles River Labs (Wilmington, MA, USA). The University of Maryland Animal Care and Use Committee approved the animal protocols. The virgins were housed in individual hanging cages. The dams were housed in individual nursing cages with nesting bedding until pups were weaned and then were moved into individual hanging cages. The temperature was maintained at $25^{\circ} \mathrm{C}$ and controlled lighting provided $12 \mathrm{~h}$ each of light and dark daily (light from 05.30 to 17.30 hours). Isoenergetic and isonitrogenous (20\% by weight casein) purified diets (Sabb et al. 1986) and water were provided ad libitum. The diets differed in fat (safflower oil) content: LF, $11 \%$ energy; MF, $40 \%$ energy; HF, $67 \%$ energy. The diets also differed in the amount of cellulose, which is a non-energetic dietary component used to maintain energy density: $5 \%, 20.2 \%$ and $34.8 \%$ by weight, respectively, in LF, MF and HF. Cellulose has been shown not to affect the dietary regulation of the pancreas (Schneeman \& Gallaher, 1980). All rats were killed by $\mathrm{CO}_{2}$ inhalation, and the pancreas was removed and divided. One half was frozen on dry ice and stored at $-80^{\circ} \mathrm{C}$ for later enzyme analysis; the other half was immediately homogenized for RNA isolation and mRNA quantification.

Expt 1. To determine the effects of lactation on PL regulation, virgin and pregnant rats (56 d old) were fed LF diet. Virgin rats ( $n$ 12) were fed LF diet for $7 \mathrm{~d}$ and killed. Pregnant rats $(n$ 18) arrived $8 \mathrm{~d}$ before parturition and, after $24 \mathrm{~h}$ on rat chow (Purina Prolab 3000; Richmond, IN, USA), were switched to LF diet. Litter size was reduced on day 9 to eleven to thirteen without regard to sex of pup to standardize litter size and milk availability and to allow an initial period undisturbed postpartum After the dams delivered, they were killed on day 0 (postpartum, $n$ 6), day 15 (lactation, $n$ 6) or day 56 (post-lactation, $n$ 6). Because we have previously shown that PL activity is maximal at 2 months of age in the Sprague-Dawley rat and does not change in the young adult (6 months of age) rat (Brannon et al. 1993), we used only one age of young virgin rats (2 months old) for comparison with the postpartum ( 2 months old), lactating (2.5 months) and post-lactating (4 months) rats.

Expt 2. To determine the interactive effects of dietary fat and lactation on PL regulation, thirty-six pregnant rats were fed LF diet until day 9 postpartum when they were randomly assigned to one of three dietary groups: LF ( $n$ 12), MF ( $n$ 12) and HF (n 12). On days 15 (lactation) and 56 (post-lactation), six dams from each diet group were killed by $\mathrm{CO}_{2}$ inhalation and the pancreas was removed and divided into two samples, one for enzyme analysis and one for RNA isolation. Sample size in both experiments was determined by power analysis (Cohen, 1988) to detect a $50 \%$ change in recombinant PL mRNA with an estimated population variance of $30 \%$ (based on previous studies in postweanling and adult rats).

\section{Pancreatic lipase analysis}

Pancreatic samples were homogenized in nine volumes of PBS (0.15 mol NaCl/l, $\left.5 \mathrm{mmol} \mathrm{PO}_{4}^{3-} / 1, \mathrm{pH} 7.4\right)$ as described previously (Ricketts \& Brannon, 1994). Lipase activity was analysed by automatic titration (Sabb et al. 1986) with $20 \mathrm{mmol} \mathrm{NaOH} / \mathrm{l}$ using a gum-stabilized emulsion of neutralized triolein with excess crude colipase. Lipase activity is expressed as units ( $\mu \mathrm{mol}$ fatty acid liberated $/ \mathrm{min}$ ) relative to mass of protein (U/mg protein) and total mass of pancreas (U/pancreas) because of the hypertrophy of the pancreas. Protein was determined by the procedure of Lowry et al. (1951) using bovine serum albumin as the standard. Protein was expressed as total $\mathrm{mg}$ protein/pancreas.

\section{Quantification of $m R N A$}

Total RNA was isolated by the method of Chomczynski \& Sacchi (1987). After collection, a pancreatic fragment was immediately homogenized with a Polytron homogenizer at $70 \%$ power for $2 \times 15 \mathrm{~s}$ in ice-cold guanidine thiocyanate $(4 \mathrm{~mol} / \mathrm{l})$, sodium citrate ( $0.75 \mathrm{~mol} / \mathrm{l}, \mathrm{pH} 7.5)$, sarcosyl (Solution D; 10\%) and $\beta$-mercaptoethanol $(0.14 \mathrm{~mol} / \mathrm{l})$. Ice-cold sodium acetate $(2 \mathrm{~mol} / \mathrm{l}$, $\mathrm{pH} 4$ ), phenol and chloroform were added and samples were centrifuged at $7500 \mathrm{~g}$ for $20 \mathrm{~min}$. The aqueous phase was removed, isopropranol was added and the sample allowed to stand for $5 \mathrm{~min}$ before being centrifuged at $12000 \mathrm{~g}$ for $10 \mathrm{~min}$. Supernatant was removed, and RNA was differentially precipitated with ethanol. The pellet was re-suspended in Solution $\mathrm{D}$, and the extraction repeated. RNA integrity was confirmed by the presence of intact $28 \mathrm{~S}$ bands by agarose gel electrophoresis. Sample RNA concentration was determined via measurement of absorbance at $260 \mathrm{~nm}$ on a DU 640 spectrophotometer (Beckman Coulter Inc., Fullerton, CA, USA). PL mRNA and 28S RNA were quantified by dot blot hybridization as described previously (Ricketts \& Brannon, 1994) using $\left[{ }^{32} \mathrm{P}\right]$-random prime (PL) and nick-translated (28S) labelled cDNA probes. Briefly, hybridization was performed at $42^{\circ} \mathrm{C}$ for $16-18 \mathrm{~h}$ after adding the $\left[{ }^{32} \mathrm{P}\right]-$ labelled cDNA probe. After hybridization, filters were washed under increasingly stringent conditions $(1 \times$ standard saline citrate with $1 \%$ SDS to $0.2 \mathrm{M}$-saline citrate with $1 \%$ SDS). The films were autoradiographed overnight at $-80^{\circ} \mathrm{C}$. The mRNA was then quantified by area densitometry using an Area Densitometer (BioRad Laboratories, Hercules, CA, USA) with Molecular Analyst software. The PL probe (rPL-3, 1.5 kb insert Eco RI of puc; Wishart et al. 1993) was a generous gift from J. Williams, University of Michigan and the $28 \mathrm{~S}$ probe was a generous gift from D. Soprano, Temple University, Philadelphia. Each probe yields a single band by Northern analysis (Tsai et al. 1994). The linearity of the dot blot hybridization was previously described for PL (Tsai et al. 1994). The specificity of the PL cDNA has also been described previously, and there is no cross-hybridization of the PL cDNA with either pancreatic lipase-related protein-1 (Tsai et al. 1994) or pancreatic lipaserelated protein-2 (Birk et al. 2004). This, coupled with the single band on Northern blots, demonstrates the specificity of this dot blot hybridization for PL under the highly stringent conditions used in this study.

\section{Statistical analysis}

Data are expressed as means with their standard error. For Expt 1, data were analysed by one-way ANOVA and Tukey's test (Sigma Stat; SPSS Inc., Chicago, IL, USA). For Expt 2, data were analysed by two-way ANOVA and Tukey's test. (Sigma Stat). Differences were determined to be significant if $P<0.05$. 


\section{Results}

\section{Expt 1: effect of lactation}

Food intake of lactating rats increased significantly (323\%, $P<0.001)$ compared with that of the virgin, postpartum and post-lactating rats (Table 1). Body weight of dams increased significantly $(50 \%, P<0 \cdot 001)$ postpartum (day 0$)$ and then remained stable throughout lactation and post-lactation (Table 1). Pancreatic weight was significantly higher in lactating rats (156\%, $P<0 \cdot 001)$ compared with the virgin, postpartum and post-lactation groups (Table 1), as was total pancreatic protein $(168 \%$; $P<0.001$; Table 1). PL activity whether expressed as $\mathrm{U} / \mathrm{mg}$ protein (Fig. 1) or total U/pancreas (data not shown) decreased significantly by $30-63 \%$ post-lactation. When expressed as U/mg protein, PL activity was not significantly different among virgins, postpartum or lactating rats (Fig. 1). In lactation and post-lactation, PL mRNA decreased significantly $(67 \%$ and $75 \%$, respectively, $P<0.001)$ compared with virgins or postpartum rats (Fig. 2).

\section{Expt 2: effect of diet and lactation}

There was a significant effect of lactation on food intake $(250 \%$, $P<0.001$; Table 2) and pancreatic weight (137\%, $P<0.001$; Table 2). Food intake, body weight and pancreatic weight were not affected by amount of dietary fat (Table 2). There was a significant independent effect of dietary fat on PL activity expressed as $\mathrm{U} / \mathrm{mg}$ protein $(\mathrm{LF}<\mathrm{MF}=\mathrm{HF}, P<0.006$; Fig. 3) and on $\mathrm{PL}$ mRNA (LF $<$ MF $<$ HF, $P<0.001$; Fig. 4). There was no significant effect of diet on PL activity expressed as total U/pancreas (data not shown). Post-lactation significantly decreased PL activity (Fig. 3), but had no independent effect on PL mRNA (Fig. 4). There was also a significant interaction between diet and lactation $(P<0 \cdot 05)$ on PL mRNA (Fig. 4).

\section{Discussion}

\section{Expt 1: effect of lactation}

The present results during lactation confirm the hyperphagia (3-fold) and hypertrophy of the pancreas (1.5-fold) reported previously (Barrowman \& Mayston, 1973; Williamson, 1980; Shirley, 1984; Matsuda et al. 1995), and emphasize the growing need of the dam for energy to produce milk. Despite the hypertrophy of the pancreas, PL activity levels during lactation were not changed. Surprisingly, although post-lactating rats reduced their food intake and pancreatic weight to levels comparable to virgins

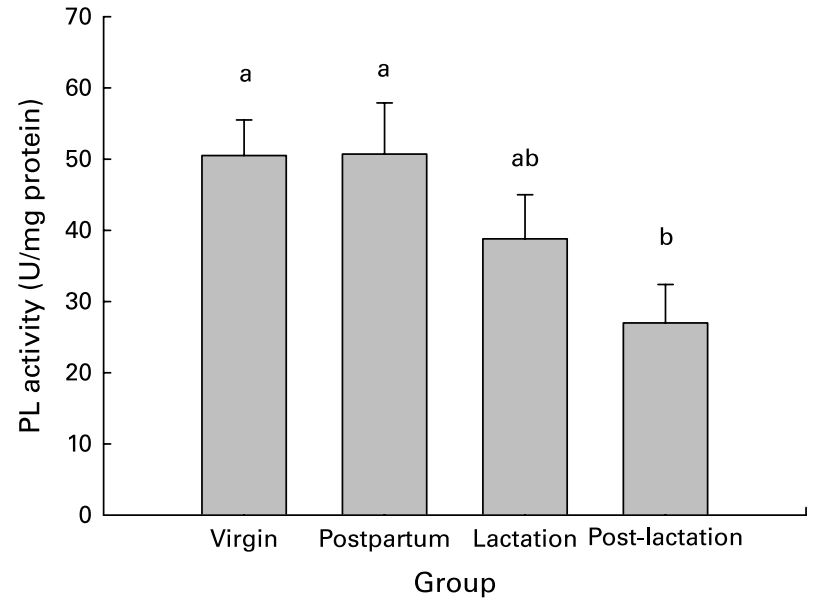

Fig. 1. Pancreatic lipase (PL) activity (U/mg protein) in lactating and non-lactating rats fed a low-fat diet. Mean values with unlike superscript letters were significantly different $(P<0.02)$.

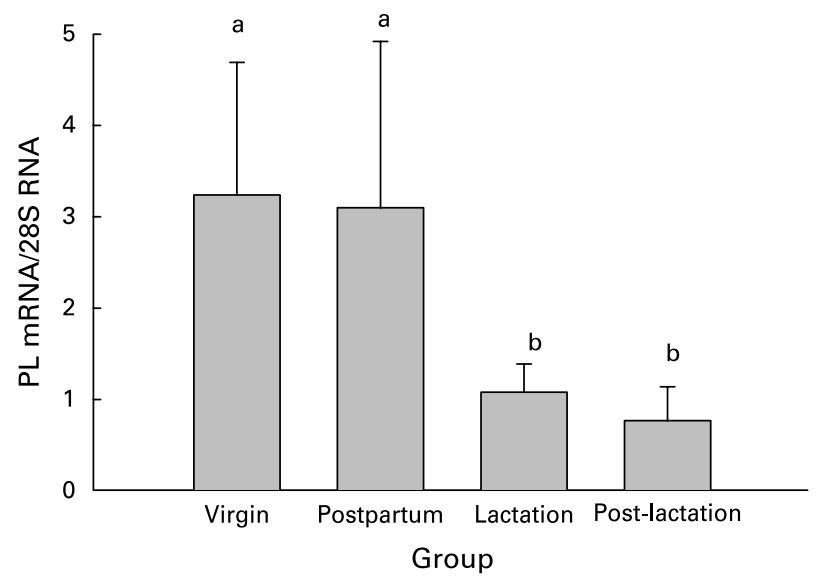

Fig. 2. Pancreatic lipase (PL) mRNA/28S RNA for lactating and non-lactating rats fed a low-fat diet. Values are means with their standard errors shown by vertical bars. Mean values with unlike superscript letters were significantly different $(P<0.001)$.

and postpartum rats, PL activity decreased significantly (75\%). The significant reduction in PL activity in post-lactating rats may be a result of decreased PL synthesis or increased secretion of the enzyme. There was a significant reduction in PL mRNA levels of lactating and post-lactating rats $(67 \%$ and $75 \%$, respectively, $P<0 \cdot 001)$ compared with virgins and postpartum rats. The accompanying reduction in PL mRNA and PL activity levels of

Table 1. Expt 1: effect of lactation on food intake, body and pancreatic weights and total pancreatic protein (Mean values with their standard error)

\begin{tabular}{|c|c|c|c|c|c|c|c|c|}
\hline \multirow[b]{2}{*}{ Experimental group } & \multicolumn{2}{|c|}{ Food intake (g) } & \multicolumn{2}{|c|}{ Body weight (g) } & \multicolumn{2}{|c|}{$\begin{array}{l}\text { Pancreatic } \\
\text { weight }(\mathrm{g})\end{array}$} & \multicolumn{2}{|c|}{$\begin{array}{c}\text { Total pancreatic } \\
\text { protein } \\
\text { (mg/pancreas) }\end{array}$} \\
\hline & Mean & SE & Mean & SE & Mean & SE & Mean & SE \\
\hline Virgin & $13^{a}$ & 4 & $206^{a}$ & 3 & $0.60^{\mathrm{a}}$ & 0.02 & $87^{a}$ & 8 \\
\hline Post-partum (day 0) & $20^{a}$ & 2 & $310^{\mathrm{b}}$ & 4 & $0.70^{\mathrm{a}}$ & 0.00 & $90^{\mathrm{a}}$ & 12 \\
\hline Lactation (day 15) & $55^{\mathrm{b}}$ & 8 & $304^{\mathrm{b}}$ & 6 & $1.03^{b}$ & 0.03 & $146^{\mathrm{b}}$ & 13 \\
\hline Post-lactation (day 56) & $22^{a}$ & 1 & $296^{b}$ & 15 & $0.75^{a}$ & 0.08 & $83^{a}$ & 9 \\
\hline
\end{tabular}

a,b Mean values within a column with unlike superscript letters were significantly different $(P<0.001)$. 
Table 2. Expt 2: effect of diet and lactation on food intake and body and pancreatic weights*

(Mean values with their standard error)

\begin{tabular}{|c|c|c|c|c|c|c|c|}
\hline \multirow[b]{2}{*}{ Experimental group } & \multirow[b]{2}{*}{ Diet } & \multicolumn{2}{|c|}{$\begin{array}{c}\text { Food } \\
\text { intake }(\mathrm{g})\end{array}$} & \multicolumn{2}{|c|}{$\begin{array}{c}\text { Body } \\
\text { weight (g) }\end{array}$} & \multicolumn{2}{|c|}{$\begin{array}{l}\text { Pancreatic } \\
\text { weight }(\mathrm{g})\end{array}$} \\
\hline & & Mean & SE & Mean & SE & Mean & SE \\
\hline \multirow[t]{3}{*}{ Lactation (day 15) } & LF & $55^{\mathrm{b}}$ & 8 & 304 & 6 & $1.03^{b}$ & 0.03 \\
\hline & MF & $56^{\mathrm{b}}$ & 4 & 307 & 8 & $1.07^{b}$ & 0.01 \\
\hline & $\mathrm{HF}$ & $52^{b}$ & 11 & 291 & 5 & $1.08^{b}$ & 0.04 \\
\hline \multirow[t]{3}{*}{ Post-lactation (day 56) } & LF & $22^{\mathrm{a}}$ & 1 & 296 & 15 & $0.75^{a}$ & 0.08 \\
\hline & $\mathrm{MF}$ & $23^{a}$ & 2 & 283 & 9 & $0.77^{\mathrm{a}}$ & 0.11 \\
\hline & $\mathrm{HF}$ & $25^{\mathrm{a}}$ & 1 & 303 & 9 & $0.80^{\mathrm{a}}$ & 0.03 \\
\hline
\end{tabular}

a,b Mean values within a column with unlike superscript letters were significantly different as determined by two-way ANOVA $(P<0.001)$. ${ }^{*}$ There was no effect of diet, or interactive effect of diet $\times$ lactation.

post-lactating rats suggests a transcriptional mechanism mediating PL activity levels.

Given the marked increase (3-fold) in food intake during lactation, it would seem that the digestive capacity of rats would also have to increase at this time. The lack of effect in PL activity and the significantly reduced PL mRNA (67\%) during peak lactation were unexpected. It is unlikely that these effects are due to maturation during this 2-month experimental period as we have previously shown that PL activity reaches maximal levels at 2 months of age in Sprague-Dawley rats and is maintained at maximal levels in the young adult at 6 months and even in the older adult animal at 18 months (Brannon et al. 1993). Further, Mizoguchi \& Imamichi (1987) found a similar and surprising reduction in pancreatic amylase activity in lactating rats due to reduction in amylase synthesis. The discordant changes between PL activity and PL mRNA levels suggest that lactation also regulates PL synthesis post-transcriptionally. Another possibility is that during lactation the synthesis of PL is reduced but the secretion is also reduced, resulting in accumulation of PL. However, this latter possibility seems unlikely in terms of the documented increase overall of pancreatic secretion with a $37 \%$ increase in volume, an $86 \%$ increase in protein and a $35 \%$ increase in amylase in basal pancreatic secretion and similar increases in



Fig. 3. Pancreatic lipase activity (U/mg protein) in lactating ( $\square$ ) and post-lactating (口) rats fed a low-fat (LF), moderate-fat (MF) or high-fat (HF) diet. Values are means with their standard errors shown by vertical bars. Mean values with unlike superscript letters were significantly different as deter-

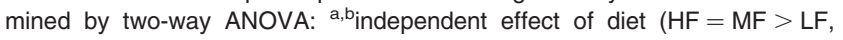
$P<0.006)$. There was no significant effect of diet $\times$ lactation. cholecystokinin-stimulated secretion (Barrowman \& Mayston, 1973). Total lipid absorption, as measured by radiolabelled NEFA absorption, also increased by $13 \%$ (Oller do Nascimento \& Williamson, 1986). Given that pancreatic enzymes are secreted in an excess of 3- to 10-fold, it seems possible that existing enzymatic secretions may adequately digest the additional food intake during lactation. The increased lipid absorptive capacity found by Oller do Nascimento \& Williamson (1986) was measured using radiolabelled NEFA and thus was not dependent on lumenal lipolytic activity. The present results, the lack of a significant increase in any of the measurements of PL activity during lactation, do suggest that existing levels of PL are sufficient to digest the increased food intake. Alternatively, the lack of response in PL activity may reflect a greater role for either lingual or gastric lipase in the rat and man, respectively. Future studies should examine the regulation of lingual lipase by lactation in the rat. Less likely is a greater role for pancreatic-related protein-2, which has a broad array of lipolytic activity (Payne et al. 1994) against glycolipids, phospholipids,

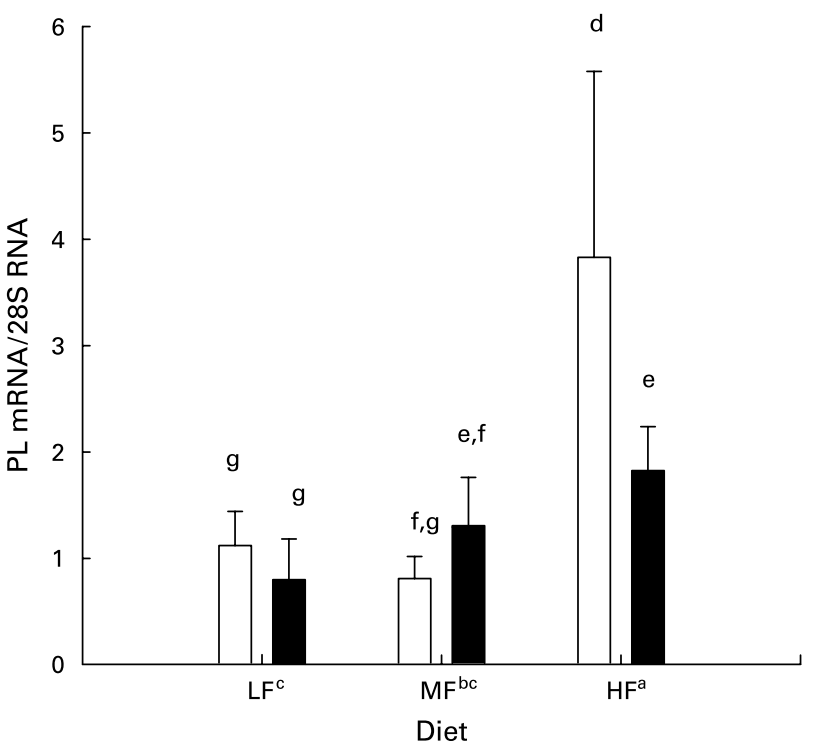

Fig. 4. Pancreatic lipase (PL) mRNA/28S RNA in lactating ( $\square$ ) and post-lactating $(\mathbf{\square})$ rats fed a low-fat (LF), moderate-fat (MF) or high-fat (HF) diet. Values are means with their standard errors shown by vertical bars. Mean values with unlike superscript letters were significantly different as determined by two-way ANOVA: ${ }^{a, b, c}$ independent effect of diet $(H F>M F=L F$, $P<0.001)$; d,e,f,ginteractive effect of diet $\times$ lactation $(P<0.01)$. There was no independent effect of lactation. 
triacylglycerols, etc., but which is expressed in the early postnatal period and is not detectable in the post-weaning Sprague-Dawley rat (Payne et al. 1994; Birk et al. 2004).

Studies investigating the regulation of PL activity with elevated dietary fat have done so by manipulating the ratio of fat to other macronutrients in the diet (Sabb et al. 1986; Wicker et al. 1988; Wicker \& Puigserver, 1990; Ricketts \& Brannon, 1994). During lactation, the total amount of dietary fat consumed daily increases from $1.4 \mathrm{~g}$ to $6.1 \mathrm{~g}$, but it does so without a change in dietary composition. Although total dietary fat consumed increases during lactation, the amount of fat in relationship to the amount of protein and carbohydrate did not change. It may be that the dietary regulation of PL is the result of the change in the proportion of dietary fat in relation to the other macronutrients, rather than to the change in the total amount of dietary fat itself. To test whether in lactation and postlactation PL is regulated by the amount and proportion of fat to other nutrients, a second experiment was conducted.

\section{Expt 2: effect of diet and lactation}

Increasing the amount of fat in the diet increased PL activity and mRNA during lactation and post-lactation similarly to that reported in male rats (Sabb et al. 1986; Wicker et al. 1988; Wicker \& Puigserver, 1990; Ricketts \& Brannon, 1994). The PL mRNA of lactating rats fed HF diet reached a maximal response and was significantly higher than the PL mRNA levels in rats fed either LF or MF diet (316\% and $167 \%$, respectively). The two metabolic situations, lactating and post-lactating, were not different with regard to PL mRNA, but there was an interactive effect on PL mRNA of dietary fat and lactation. The PL mRNA levels of the post-lactating (day 56) rats fed HF diet reached a maximal response and were significantly higher than those of the post-lactating rats fed LF diet (193\%), but not those fed MF diet (100\%). The independent and opposite effects of lactation and diet on PL activity and mRNA suggest a translational or post-translational regulatory mechanism for PL activity during lactation. Finally, the decrease in PL activity and mRNA in post-lactation must be investigated further to determine the mechanism.

\section{Summary}

Lactation and post-lactation significantly reduce PL mRNA levels compared with either postpartum or virgin rats. The maintenance of PL activity during lactation suggests that compensatory changes occur in its translation or post-translation. Despite the effects of post-lactation on PL mRNA and activity, the amount of fat in the diet does significantly regulate PL in both lactating and post-lactating rats.

\section{Acknowledgements}

The work was supported in part by the Maryland Agricultural Experiment Station, grant NFSC-97-72. All authors contributed equally to this manuscript.

\section{References}

Barrowman JA \& Mayston PD (1973) Pancreatic secretion in lactating rats. J Physiol 229, 41P-42P.

Birk RZ, Regan KS, Boyle-Roden E \& Brannon PM (2004) Pancreatic lipase and its related protein 2 are regulated by dietary polyunsaturated fat during the postnatal development of the rat. Pediatr Res 56, 256-262.

Brannon PM, Kunz SG \& Reid BL (1993) Effects of aging and acute food restriction on the exocrine pancreas in Sprague-Dawley rats. FASEB J A815.

Carriere F, Barrowman JA, Verger R \& Langier R (1993) Secretion and contribution to lipolysis of gastric and pancreatic lipase during a test meal in humans. Gastroenterology 105, 876-888.

Chomczynski P \& Sacchi N (1987) Single-step method of RNA isolation by acid guanidinium thiocyanate-phenol-chloroform extraction. Anal Biochem 162, 156-159.

Cohen J (1988) Statistical Power Analysis for the Behavioral Sciences, pp. 273-403. Mahwah, NJ: Lawrence Erlbaum Associates.

Cripps AW \& Williams VJ (1975) The effect of pregnancy and lactation on food intake, gastrointestinal anatomy and the absorptive capacity of the small intestine in the albino rat. Br J Nutr 33, 17-32.

Garcia-Caballero T, Morel G, Gallego R, Fraga M, Pintos E, Gago D, Vonderhaar BK \& Beiras A (1996) Cellular distribution of prolactin receptors in human digestive tissues. J Clin Endocrinol Metab 81, 1861-1866.

Lowry OH, Rosebrough NJ, Farr AL \& Randall RJ (1951) Protein measurement with Folin phenol reagent. J Biol Chem 193, $265-275$.

Mainoya JR (1975) Effect of prolactin on sugar and amino acid transport by the rat jejunum. $J$ Exp Zool 192, 149-154.

Mainoya JR (1978) Possible influence of prolactin on intestinal hypertrophy in pregnant and lactating rats. Experientia 34, 1230-1231.

Matsuda M, Mori T, Park MK \& Kawashima S (1995) Modification of pancreatic digestive function by pituitary grafting in mice. Eur $J$ Endocrinol 133, 221-226.

Mizoguchi J \& Imamichi T (1987) Decrease in amylase (EC 3.4.21.4) synthesis in lactating rats. Br J Nutr 57, 291-299.

Oller do Nascimento CM \& Williamson DH (1986) Evidence for conservation of dietary lipid in the rat during lactation and the immediate period after removal of the litter. Decreased oxidation of oral $\left[1-{ }^{14}\right.$ C]triolein. Biochem J 239, 233-236.

Payne RM, Sims MF, Jennens ML \& Lowe ME (1994) Rat pancreatic lipase and two related proteins: enzymatic properties and mRNA expression during development. Am J Physiol 266, G914-G921.

Regan KS, Birk RZ\& Brannon PM (1999) The effect of lactation and dietary fat on the gene expression of pancreatic lipase. FASEB J 13, A697.

Ricketts J \& Brannon PM (1994) Amount and type of dietary fat regulate pancreatic lipase gene expression in rats. J Nutr 124, 1166-1171.

Roberts SB \& Coward WA (1984) Lactation increases the efficiency of energy utilization in rats. J Nutr 114, 2193-2200.

Sabb JE, Godfrey PM \& Brannon PM (1986) Adaptive response of rat pancreatic lipase to dietary fat: effects of amount and type of fat. J Nutr 116, 892-899.

Schneeman BO \& Gallaher DD (1980) Changes in small intestinal digestive enzymes activity and bile acids with dietary cellulose in rats. J Nutr 110, 584-590.

Shirley B (1984) The food intake of rats during pregnancy and lactation. Lab Anim Sci 34, 169-172.

Tsai A, Cowan R, Johnson DG \& Brannon PM (1994) Regulation of pancreatic amylase and lipase gene expression by diet and insulin in diabetic rats. Am J Physiol 267, G575-G583.

Wicker C \& Puigserver A (1990) Expression of rat pancreatic lipase gene is modulated by a lipid-rich diet at a transcriptional level. Biochem Biophys Res Commun 166, 358-364.

Wicker C, Scheele GA \& Puigserver A (1988) Pancreatic adaptation to dietary lipids is mediated by changes in lipase mRNA. Biochimie 70, 1277-1283.

Williamson DH (1980) Integration of metabolism of tissues of the lactating rat. FEBS Lett 117, K93-K104.

Wishart MJ, Andrews PC, Nichols R, Blevis GT, Logsdon CD \& Williams JA (1993) Identification and cloning of the GP-3 from rat pancreatic acinar zymogen granules as a glycosylated membrane-associated lipase. J Biol Chem 268, 10303-10311. 